\section{THE STUDY OF MATERIAL CULTURE OF THE IBAN COMMUNITY IN SARAWAK: NGEPAN}

\author{
Noria Tugang \\ University Malaysia Sarawak \\ Gregory Kiyai @ Keai \\ University Malaysia Sarawak
}

Corresponding Author gregory kiyai@yahoo.com
Cultural identity is a specific word that refers to individuals and communities in distinguishing themselves from others. One of the most dominant identities in a community culture is traditional clothing. In Sarawak, the traditional dress for the Iban is commonly known as Ngepan Indu. The Ngepan Indu is often worn during the Gawai Dayak celebration season as well as several other ritual ceremonies such as the Miring ceremony (Offerings) and Melah Pinang (Marriage). The Iban community believes that the Ngepan Iban is an identity and cultural icon in today's customs. Apart from that, Ngepan Iban is one of the treasures and legacies of Petara (God) who inhabited a kingdom called Panggau Libau, Tinting Gawai Gasing Gerah Layang so that Iban always remembered Petara and the origin of Iban's ancestors. This paper aims to analyze and understand the Ngepan Indu in the context of the custom and culture of the Iban community by using the qualitative research method based on the collective memory of the Iban cultural experts in Sarawak. Through this research, it is expected to have an effective and progressive impact to regenerate the spirit of Iban culture to continue persistently preserve the Ngepan Iban as a cultural heritage from the ancestors of the past, so that it will continue to be preserved for the future.

Keywords: Culture, costume, identity, Iban, Ngepan, heritage. 


\section{INTRODUCTION}

Identity is a characteristic to introduce or to distinguish one thing from another. For the name that was given to each human being is one a sign that to distinguishes from the others. (Yussof, 2006: 13) stated that the word identity carries a more comprehensive meaning than the word individuality. Individuality in the context of identity is interpreted as self-strength based on the inherited tradition or authenticity that is within oneself. The identity referred to in the context of this discussion refers to self-strength which is expressed based on a symbol, icon, or a sign for society and culture. In addition, (Ennaji, 2005) said that cultural identity refers to feelings or attitudes that indicate that an individual belongs to a certain community and ethnic group. At the same time, this cultural identity becomes part of the individual's self-perception which includes language, religion, culture, social status, heredity, and culture. The similarity of these aspects makes the individual feel part of the community by sharing these characteristics.

\subsection{Definition of Cultural Identity}

Cultural expert (Hall, 1990) said that in general, the concept of cultural identity is formed from history and past experiences. This culture has formed equality in society. However, the cultural identity that has been formed has the potential to change or survive through the influence of the media in this era of globalization. Hall's statement is supported by (Fong and Chuang, 2003: 76) that historical factors play an important role in shaping the cultural identity of a group of people and in the end, it will produce shared characteristics. Although cultural identities have succeeded in forming unification between groups of people, however, the characteristics that come from these historical factors have the potential to change over time. The transformation that occurs in this cultural identity has an impact on changes in community groups in the context of cultural heritage, mother tongue, norms, religion, beliefs, and so on. This is also stated by (Bernadette and Elmhurst, 2008: 5-7) who said that apart from history, geographical factors are also a factor in the formation of indigenous culture through culture, music, dance, and way of life.

\subsection{Definition of Traditional Costume}

According to the (Kamus Dewan Bahasa III, 1994) traditional costume is a complete and beautiful custom clothing containing jewellery. While traditional is a word related to nature or according to traditions or people who practice this way of life from generation to generation. (Sholikhah, 2017) also supported that ethnic clothing is referred to as traditional clothing, which is a regional dress that has been worn from generation to generation, which is one of the identities and can be proud of by most supporters of certain cultures. Traditional clothing includes a symbol of identity, social status, way of 
life, and technology skills to shape society. The identification of the races in this world, apart from being identified through physical and way of life, the style of dress is also one of the special characteristics in introducing people's abstract identity. For example, people in China are known to wear Cheongsam and Indians wear Saris, while the Dayak Iban in Sarawak and Kalimantan is known to wear the Ngepan Iban.

\section{LITERATURE REVIEW}

Iban is one of the largest sub ethnics in Dayak community living in Sarawak (a part of Borneo Island). Sarawak were famous with epithet as the land of hornbills. Sarawak is a state located in northwest of the island of Borneo and overlooks the South China Sea. With an area of 124,450 square kilometres, Sarawak became the largest state in Malaysia. The extent of Sarawak covers about 48,000 square miles with a beach area. The topography of Sarawak consists of mountainous areas in the southeast and lowlands in the northwest of about 500 miles long and has altitude of between 2,500 to 4,000 feet above sea level. Sarawak border with Kalimantan, Indonesia, Brunei and Sabah (Ismail and Noor, 2019).

The early migration of the Iban community can be identified based on oral traditions and historical sources. They believed that the Iban people migrated more than 600 years ago from Kapuas, Kalimantan. But referring on (Simonson et al, 2011) genetic research, early human migration across the Sunda land route connecting the land of Southeast Asia has occurred about 45, 000 to 50, 000 years ago. Evidence of genetic sampling suggests that the theory of Austronesian society originated in southern Taiwan is unlikely. Recent research based on DNA analysis has concluded that migration from mainland Southeast Asia only occurred in the same range. It is predicted that several lineages associated with the prehistoric migration of the last ice age have created a wave of migration through the ISEA coastline. The Iban community believed to be among those involved in the early migration. This fact is based on the discovery of primitive human fossils that have been excavated near the modern settlement of the Iban community longhouses in Niah cave, which is in Miri Sarawak. It is widely believed regarding the Iban existence in that period. As time move on, the Iban people had spread to the northern part of Borneo and identify a suitable settlement and established their ethnicity based on their surrounding nature. However, the migration progress does not halt. The mobilisation of the Iban was carried out for several generations to find suitable location to be inhabited. There are various factors that caused to the migration of the Iban community. Initially, it was for the purpose of searching fertile soil. After the culture of the Iban community is more developed, they migrate with the aim for the head-hunter expedition with the purpose of expanding power, custom and their legacy. 
According to (Sutlive, 1992), the Iban community is a branch of the Dayak ethnic group inhabited the Borneo archipelago for a long time. During the British colonial era, they were recognised as the Sea Dayak and famous for head-hunting tradition to defend their territory. In addition, (Payne, 1986) explained the socio-cultural community of the Iban people inhabit the riverbank area and carried out their activities to mature. Based on (Pringle, 1970), before the colonisation, the Iban community did not have specific term for identifying themselves like the current Iban community. However, the Iban will self-introduction themselves based on river they are currently settle in. For example, kami ari Skrang (we are Skrang) or kami ari Undop (we are Undop) even they will refer to "We of this area". If this method of identification still practices in the modern era by the Iban community in Sarawak. Now Ibanic group can be classified in two groups based on political geography: the first Ibanic who settled in Sarawak, Malaysia, namely Balau, Remun, Sebuyau, Lemanak, Skrang, Undop, Saribas and Ulu Ai. Second is referring to Ibanic in West and East Kalimantan, Indonesia, namely Mualang, Seberuang, Bugau, Kantu, Desa, Sebaruk and Banyur. However, there are three main theories about the arrival of the Iban community in Sarawak. The first theory established the arrival of the Iban people is from Tanjung Datu in Lundu. The second theory is also by referring to (Sandin, 1967: 3-26). The theory concluded the Iban migrated through Merudu Hill located near Brunei, and the third theory is the widely accepted in Iban community. The theory suggested that the Iban migration was from the Kapuas valley into Sarawak through the Kumpang area. This theory is based on the Iban community's oral traditions told from generation to generation with the journey of Aki Lang Sengalang Burong (God). Aki Lang Sengalang Burung had migrated from Tampun Juah and stopped in the area stated above.

The culture inherited in the Iban community has existed for hundreds of years created by their ancestors. The culture was shared by many in order to form their identity as the Iban people. The Iban people believe that the culture they practice today is a gift from the God called Petara. Based on the Iban oral tradition, the Iban explains that once upon a time the Iban people and Petara communities lived together in a place called Tembawai Tampun Juah. The relationship between the Iban and Petara was temporary. The separation between mortal and divine happened as the result of conflict. Although the Iban have been taught the method of living through Petara (gift) way of life. Therefore, the legacy left by Petara and the information gained by the oral source earlier. These two components have become the essence and identity of the Iban community until now. 


\section{RESEARCH METHOD}

This research is in the form of ethnography based on the cultural material of the Iban community in Sarawak. According to (Hanson and Creswell, 2005), an ethnographic study is a qualitative study to describe, analyze, and interpret the forms of culture sharing in a group such as behavior, belief, languages, economy, political structure, interaction, life, and relationship styles. Besides, (Darmawan, 2008) stated that ethnography is a field of study that focuses on descriptive studies, cultural analysis, linguistic that among others describe and analyze language codes. Ethnography is also an observational field study which is often used in the sociological and anthropological studies and referred to as natural scientific research (Marican, 2005). Hence, the data findings described in this paper are the thesis data of researchers which are obtained through three methods of data collection, namely field observation, interviews, and documentation.

Observation involvement of the field is a qualitative method conducted by the researchers to the Iban community settlement area. According to (Jasmi, 2012), the observation method through the involvement comes from the field of anthropology, which is the study of the community of life. Researchers usually engage with the target community to understand an issue clearly. The reason behind the usage of observation involvement technique to the field, according to (Moleong, 1989), the observation allows the researchers to see, feel, interpret the world along with various social events and social symptoms in it, as the subject sees, feels, and interprets it and the observation allows the formation of knowledge between the researcher and his subject (intersubjectivity). Three main districts have been identified in this research which are Rumah Liam, Rantau Kembayau, Manis Lubok Antu, Rumah Kunjang, Etawa Asal, Undop, Sri Aman, and Rumah Bujang, Rantau Kiran, Nanga Medamit, Limbang to conduct research method observation by community involvement.

Besides that, this research also applied a documentation method to archive the Ngepan Iban. According to (Lund et al, 2008) defined documents as the result of human effort to say, give instructions, show, teach, or perform, document briefly using specific tools and methods. Moreover, (Buckland. 2017) believed that documentation is a method of collection, selection, processing, and storage in the field of knowledge and the provision or display of shreds of evidence such as photographs, newspapers, and other data sources. The notion of documentation has evolved into more complex in describing human social events through its activities. Hence, it is used in this research to draw the cultural artifacts of the Iban community that are considered sacred in their beliefs and practices in Sarawak. 
The last method of data collection is the interview. It is divided into two target groups. The first target group used the focus group interview. Where the researchers have interviewed a group of informants living in longhouses related to history, the process, the taboo of sacred artifacts in Iban society. The second target group is the Iban community who has the expertise and proficient in Iban culture. The informants were interview (in-depth interview) based on their skills and knowledge in detail about the customs, skills, and beliefs of sacred artifacts. Collective memory technique is used as the data collection method which is consist of an individual interview (in-depth interview) and a focus group interview.

Collective Memory is a memory which is referred as a rearrangement of the past and adjusts the images, beliefs, and experiences of the present (Mead, 1929). Besides, according to (Olick, 1999: 337), Collective Memory is an action that includes collective representational factors (symbols, meanings, narratives, and rituals that exist in a society), cultural structures, and individual memories that are formed personally and socially. culture. According to Barbara (Misztal, 2003), human memory can be expressed in various forms, namely, (i) Reflective memory is a person's memory that involves interaction with the people around him. (ii) Generational memory is a memory that is passed down from the older generation to the successor or the younger generation so that the memory will continue to live in the culture. This memory causes events to continue and regress if forgotten and (iii) Traditional memory is static memory, past-oriented and conservative. Moreover, memory is resistant to change and as a tool to integrate past and present until there is balanced development. Where the informants who have been interviewed are a group of experts in Iban culture. The data collection method used to obtain data used the Collective Memory technique, namely individual interviews (in-depth interviews) and focus group interviews.

\section{RESEARCH FINDINGS}

Today, Ibanic speaking can be grouped into two categories. First lbanics that live in Sarawak, Malaysia namely Balau, Remun, Sebuyau, Lemanak, Skrang, Undup, Saribas, and Ulu Ai. The second refers to Ibanic that lives in West and East Kalimantan, Indonesia, namely Mualang, Seberuang, Bugau, Kantu, Desa, Sebaruk, and Banyur. The identification is broken down into several races which are classified according to the river, which is the settlement of the Iban community like Iban Saribas, Iban Batang Ai, Iban Batang Lupar, Iban Batang Rajang, Iban Sebuyau and Bilak Sedik. 


\subsection{Ngepan Indu Iban is based on the Myth of Kumang.}

The history of Ngepan Indu Iban cannot ascertained, since when did the Iban people start wearing it, but according to informant (Edmmund Langgu, 85 years) said that, Ngepan Indu Iban was closely related to the Dayak Iban Goddess named Kumang. Kumang (Goddess Kumang) is considered as a famous Iban legend figure, till the point that before the Gawai Dayak, there will be a beauty competition called Kumang Gawai as a sign to remember Kumang. The figure of Kumang was described as an ideal Iban woman and has various advantages such as good at weaving cloth and pua. She also has a polite personality and a beautiful face that comes from Gelong Batu Nakong, who then married to Dewa Keling (God Keling) and moved to Menua Panggau Libau.

According to (Gavin, 1991), the Iban believes that Kumang will often manifest in Iban women's dreams by giving them directions to weave motifs and patterns. The Iban woman that was chosen by Kumang through the dream must then perform a Ngar ceremony to fulfill the wishes of the people in Panggau Libau. The figure of Kumang has not only to help the Iban women, but she also helps the Iban men who want to go to war. Therefore, the Iban people have learned and imitated the way of dressing based on Urang Panggau (Elysium) life. Generally, Ngepan Iban is not only a traditional dress, but as an identity so that Petara (god) will recognize them during the ritual ceremony

\subsection{Type Ngepan Indu Iban}

According to informant (Janet Rata Noel, 50 years), the curator of the Tun Jugah Foundation said that clothing, or what is known as Ngepan is the identity of the Iban community in Sarawak, but there are some special characteristics and differences that exist in each of these traditional clothes. In the Iban culture, several types of Ngepan Iban have been identified, namely Ngepan Saribas (Betong, Paku and Krian), Ngepan Kuas (Undop, Semanggang and Lingga), Ngepan Batang Rajang (Kapit), Ngepan Batang Ai (Lubuk Antu, Lemanak and Engkelili) ) Ngepan Ringgit (Skrang) and the general Ngepan Iban (used by all the Iban). This identification is based on the name of a residential area or river close to the Iban in Sarawak. The existence of differences among the Iban communities is influenced by factors of migration and cultural adaptation to the natural surroundings. The types of Ngepan Indu Iban are as follows:

\subsubsection{Ngepan Iban Saribas}

Based on an interview with Informant (Maria Liban, 79 years old) Ngepan Saribas is Ngepan used by the Iban who domiciled in Betong, Paku, Krian, and Layar. This Ngepan has its distinctive characteristics, namely using a Rawai Tinggi (corset made from silver) which is made from silver or rattan and shaped into a circular shape 
according to the cut of the woman's hips, then decorated with silver coins. Ngepan Iban Saribas is usually combined with a Kebat cloth (Iban weaving that has a water spiral pattern), Lampit Perak (silver lampit), Sugu Tinggi (high comb/headdress), a pair of silver earrings, Kalung Perak (silver necklace), and a complete set of Tumpa Pirak (silver arm bracelet). Meanwhile, the legs will be covered with a set of silver anklets that have bells and the hands will be tucked in a white lacy handkerchief while holding the Buah Pauh as additional decoration.

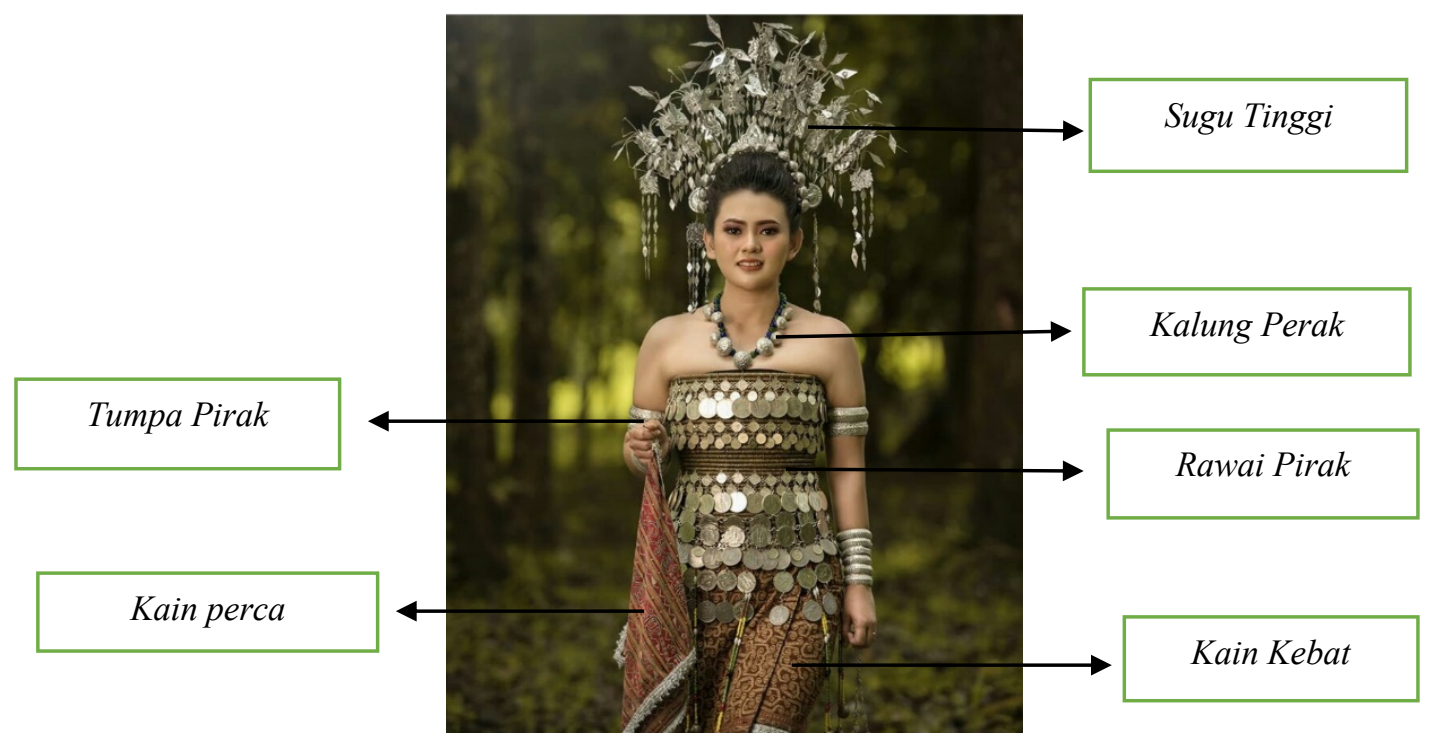

Figure 1: Ngepan Saribas (Photo by: Urai Lidum, 2019)

\subsubsection{Ngepan Batang Rajang}

According to informant (Janet Rata Noel, 50 years old), Ngepan Batang Rajang or Dujung Marik is Ngepan for the Iban who live in the Batang Rajang River refer to the Kapit, Song and Balleh area. Dunjung Marik, which means a large pile of beads is made following the Ngepan characteristic, with the predominance of beads of various colors and high quality. Meanwhile, Baju Marik clothes are made using bead embroidery techniques of various colors and categories such as glass beads, blue barrel beads, straw beads, buah pelaga (fire agate), brass bells, and cowrie shells. To complement the Ngepan Dunjung Marik style, accessories such as dunjung (headdress made of beads and paper flowers), burie cloth (cloth embroidered with snail beads), tumpa bulu (bracelet made of rubber trees), and gerunung siong will be added as a hand accessory. It is believed that the Ngepan Iban in Batang Rajang received influences from the Urang Ulu (Kayan, Kenyah, and Kelabit) culture as well as the Embaloh ethnic who were the early settlers on the Rajang River before they migrated to the highlands of Bario and Ba'kelalan 


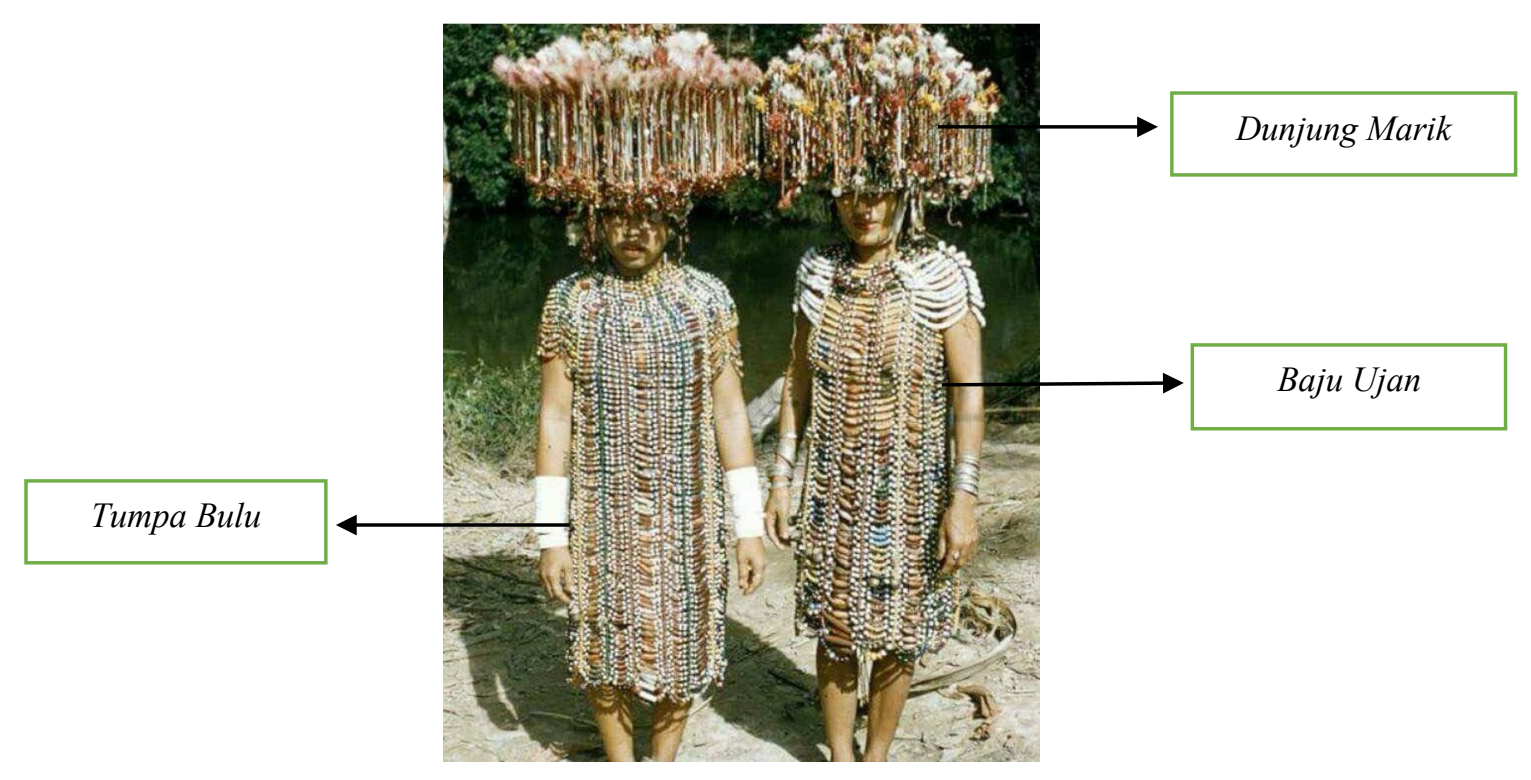

Figure 2: Ngepan Batang Rajang (1997) (Photo by: Kapit Bulletin, 2019)

\subsubsection{Ngepan Batang Ai}

Ngepan Batang Ai or Ngepan Lampit Besusu refers to the traditional dress of the Iban who lives around the Lemanak, Engkelili and Lubok Antu areas. According to (Jusy Sambai, 2018), based on his research, Ngepan Batang Ai's complete costume are Sugu Tinggi (headdress), Lampit, Tumpa Bentuk, Tumpa Rangkup Pandak, Pandak Pirak Rawai, Kain Sungkit (woven cloth), Gelang Kaki (anklets), Tali Leka Peria (silver ropes), Sementing Ringgit and Buah Pauh (hand accessories). Physically, Ngepan Batang $A i$ is almost identical to Ngepan Iban from Skrang area, but there are still significant differences that can be seen clearly. One of the examples is the use of tenun sungkit (woven textiles). According to informant (Sima Jang, 70 years old), said that the Iban in Batang Ai is more likely to produce tenun sungkit weaving than Kain Kebat (weaving fabrics). This is influenced by the kain sungkit (woven fabrics) textile which is more colorful and has more distinctive motifs than other Dayak Iban woven fabrics. Besides, the uniqueness of Ngepan Batang $\mathrm{Ai}$ is that its usage of lampit (Silver Belt) as the main accessory to cover a woman's chest. 


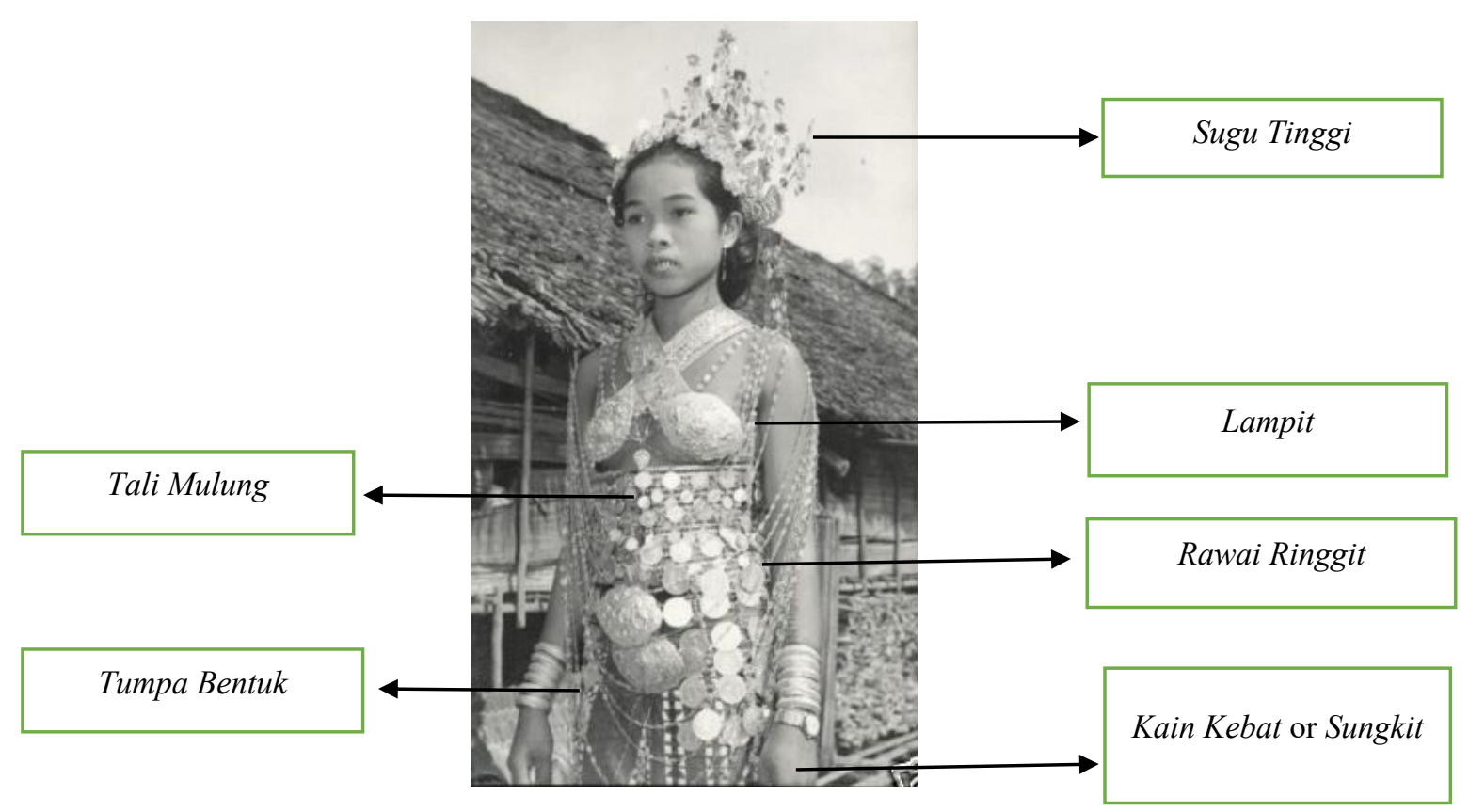

Figure 3: Ngepan Batang Ai (1891) (Photo by Sarawak Museum, 2019)

\subsubsection{Ngepan Skrang}

Ngepan Skrang, also known as Ngepan Ringgit, is a traditional costume of Dayak Iban who lives in the Skrang area. According to informant (Beol Dingin, 80 years), Ngepan Ringgit from Skrang generally uses a Sugu Tinggi (headdress), Baju Ringgit, Rawai, Kain Kebat (weaving fabric), and accessories such as Lampit Ringgit, Tumpa Pirak, Simpai Pirak, Buah Pauh, and Gerunung Kaki (bell anklet) in the arrangement of traditional clothes. The specialty of the Ngepan Ringgit is the use of silver coins from Europe as a characteristic of the Ngepan Skrang in accentuating the identity of the Iban traditional dress in Skrang. The usage of the name Ringgit was inspired by the ringgit currency in Malaysia, although the basic material for the traditional Ngepan Skrang clothing uses silver coins from Europe. 


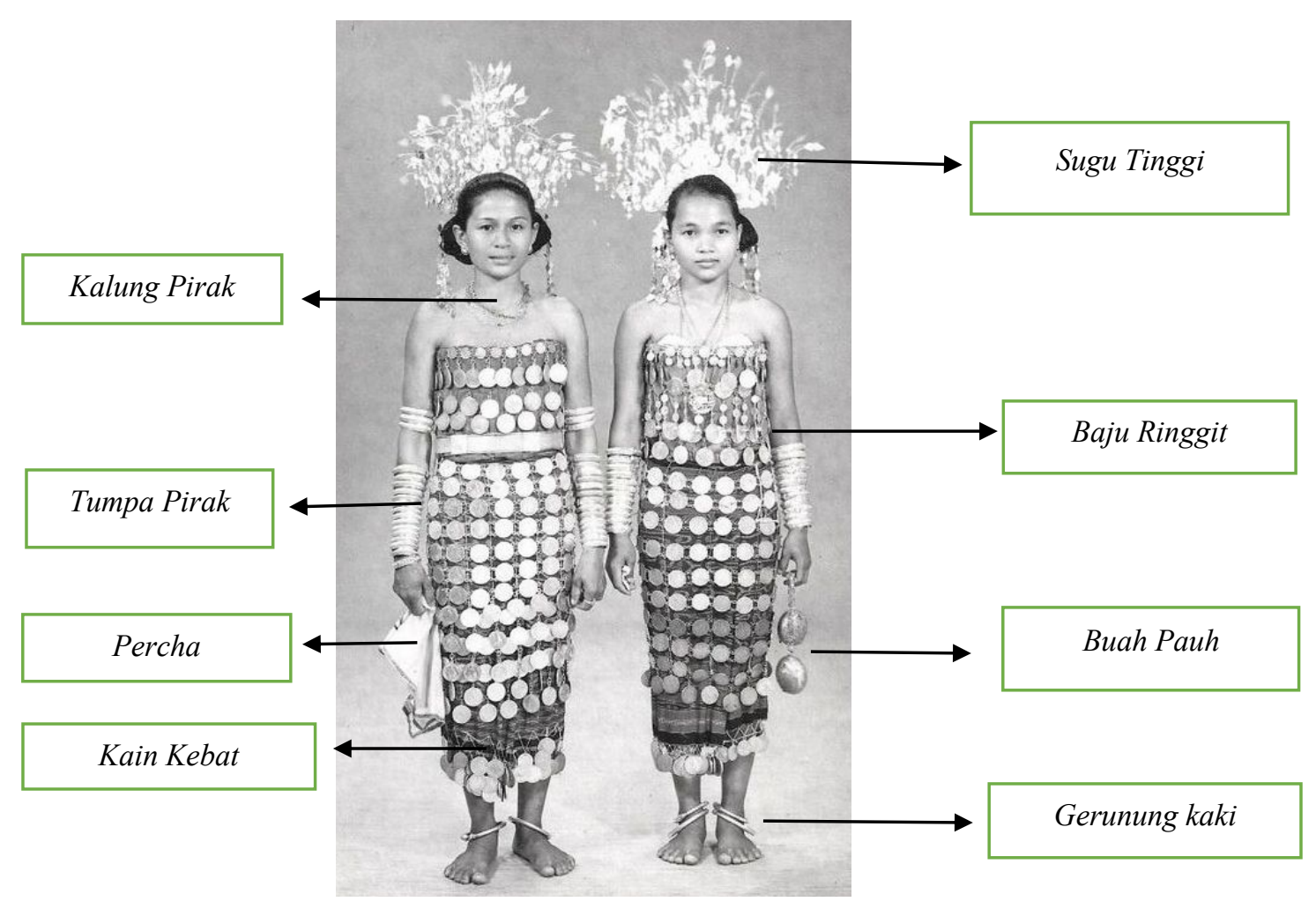

Figure 4: Ngepan Skrang (1891) (Photo by Sarawak Museum, 2019)

\subsubsection{Ngepan Iban in General}

Ngepan Iban, generally refers to the traditional costume that is identical to the Iban in Sarawak, even in Kalimantan. This type of Ngepan is not specific to a single area like the other Ngepan Iban as above. Moreover, the general Ngepan Iban is an inheritance from a the Iban family that will be passed down from generation to generation by grandmothers, mothers, parent-in-law, or spouses. According to informant (Chermai Iri, 68 years) Ngepan Iban, which is always arranged by Iban women in the Gawai Ceremony, consists of Sugu Tinggi, Tali Mulung, Rawai, Buah Pauh, Bentuk Tumpa, Gerunchung Kaki, Lampit, Sementing Ringgit, Selampai, and Tango. This type of ngepan is widely used by the Iban community as a sign of their identity to differentiate themselves from other Dayak ethnicities. 


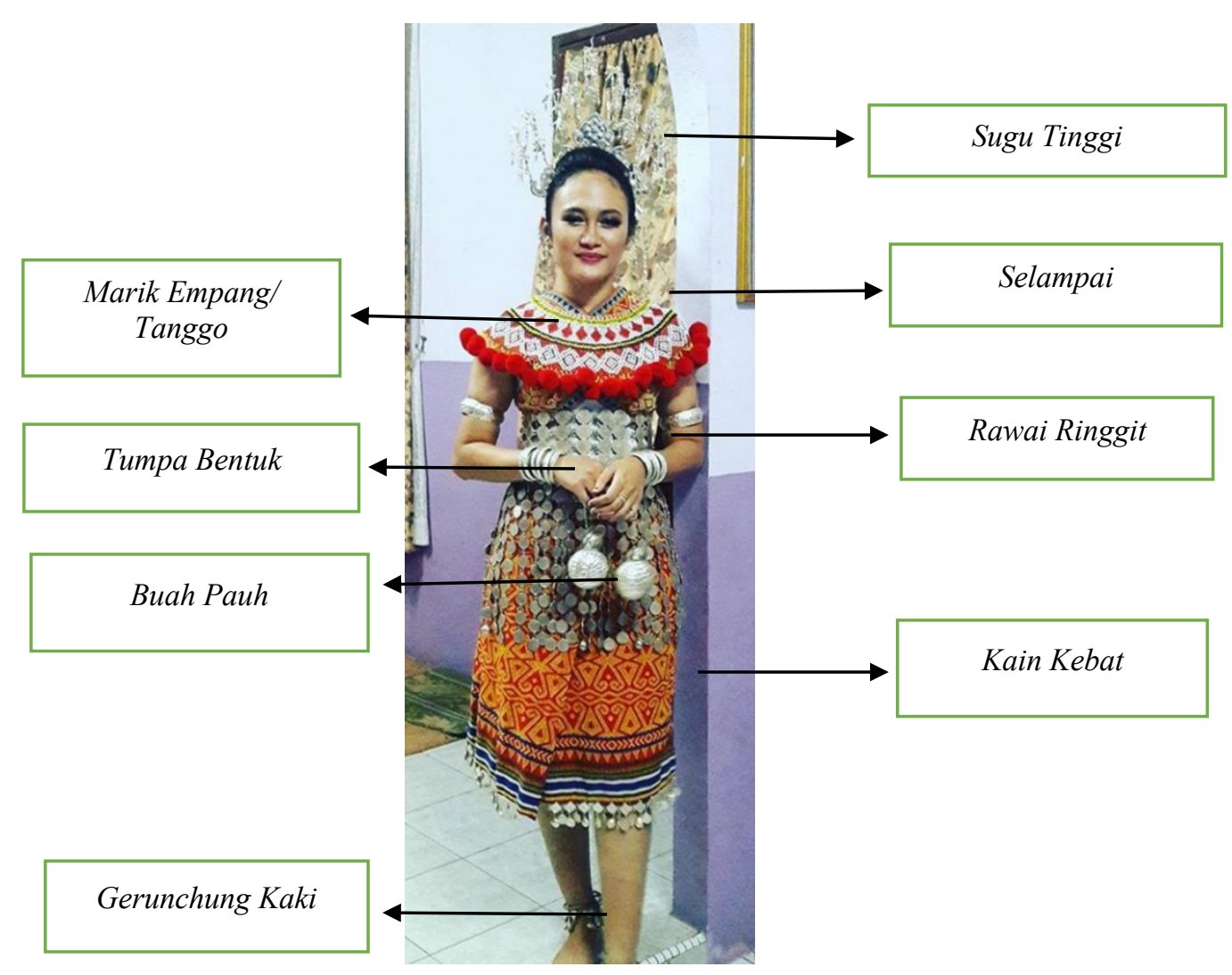

Figure 5: Ngepan Iban during Gawai Dayak (2019) (Photo by: Durasima Namieng, 2019)

\section{DATA ANALYSIS AND DATA INTERPRETATION}

Efforts to introduce and elevate Ngepan Iban as a symbol of the Iban identity to the national level began with an Iban Women's Organization in 1950. It is located at Kuching, Sarawak which is also known as Serakup Indu (Iban Woman Associates). The organization is led by Ms. Barbara Bay who has gathered the Iban women with basic education such as reading, writing, and counting from all over the Sarawak such as Lundu, Lubuk Antu, Betong, and Simanggang (currently known as Sri Aman). The objective of the establishment of this association is to improve the quality of life of the Iban, especially women in terms of education, health, economy, and socialization, especially in Iban cultures such as holding a Ngajat dance and Pua Kumbu weaving class. However, the initial effort to preserve Ngepan Iban only happened in a group of women who are involved in the association only due to a lack of skilled manpower in administering the association.

On September 25, 1964, a year after the formation of Malaysia, an Iban female political figure, the late Philomena Tra Jemat or also known as Dato Sri Tra Zehnder Jemat along with other Dayak ministers, fought for the Pesta Gawai Dayak to be held as a 
national festival to celebrate the Dayak in Sarawak especially the Iban and Bidayuh. The special declaration was given by the state government to allow Gawai Dayak Festival to be celebrated every 1st June by the Dayak community has provided a culturally friendly landscape and perspective in introducing the lban Dayak cultures and lifestyle in general to the national level. Through the Gawai Dayak Festival, Ngepan Iban has been promoted indirectly as the identity and icon of Dayak Iban traditional clothing until these days.

The beauty of women who wear Ngepan Iban is often expressed in Leka Main Iban (Oral tradition) such as Sugi, Pantun Puji, Ramban, and Ganu. Examples of compliments that are often sung by the Iban men to admire the beauty of a woman in wearing Ngepan Iban are such:

Table 1: The Metaphor of Iban Beauty

\begin{tabular}{l|l}
\hline Iban Language & English Translation \\
\hline $\begin{array}{l}\text { Rarat betis, baka lais patis ikan } \\
\text { laban }\end{array}$ & $\begin{array}{l}\text { straight and long calf section } \\
\text { resembling the shape of fish }\end{array}$ \\
\hline Lengan baka ripan buluh lalang & the small sleeves are shaped \\
& like pointed bamboo items \\
\hline Buk baka kemidin dunjang & hair that is combed and worn \\
with Sugu Tinggi likened a \\
crown
\end{tabular}


According to (Lemambang Abang Entrey, 81 years old) through the metaphor of the language, the beauty of a woman is reflected through the elements of flora and fauna within their settlement. Apart from that, the Iban also depicts the beauty of a woman through sacred figures such as Mermaid. It is not only interpreted in linguistics but also applied in the art of the Iban community as in the motifs found in Pua Kumbu and bemban weaving. In the social tradition, Ngepan is a legacy and inheritance bequeathed by a woman in a the Iban family. The inheritance process is done for generations from grandmother to mother, then to daughter or daughter-in-law and the practice takes place continuously. Indeed, Ngepan Iban has a high aesthetic value in the Iban culture. Ngepan Iban is a form of activity that involves traditional ceremonies and rituals. It is used in traditional ceremonies and rituals. For example, Gawai Tanju, Bedara, or Begawai Umai (Harvest Celebration). Apart from that, Iban women wear Ngepan Iban to welcome the return of their husbands who have returned from the Ngayau expedition. The Iban woman will wait for her husband, or the Iban man at the front of the stairs then greet the enemy's head that was obtained during the Ngayau expedition using the Pua Kumbu which has a bali belumpung or melting fire motif.

The Iban women in ancient times did not care if they became widowed at a young age when their husbands went on the Ngayau expedition, this was because they were more concerned with name and family status when their husbands returned from Ngayau (head-hunting). When carrying out the Miring (offering ceremony), the use of Ngepan Indu is mandatory, especially for Indu Piring, which is the woman who prepares and manages the equipment for the Miring (offering ceremony). It proves to Petara (God) that the Iban are serious in carrying out the ceremony to ask for help and assistance. For ordinary people who do not use Ngepan Iban, it is advisable to stay away from the offering ceremony for fear of being exposed to spiritual forces that can cause illness and lead to death. The Iban believes that during the Miring ceremony, Petara (God) and Urang Panggau (Elysium) will come to listen to the Iban requests. The shrilling sound of a Kain Tating (Iban fabric) decorated with coin ornaments will produce a melodious sound like an Emping Aling bird. It will attract the attention of a the Iban man to choose his future wife candidate. In the past, the Iban, especially mothers who intend to find a daughter-in-law, paid close attention to the perfection of Iban women who wear Ngepan Iban, especially unmarried Iban women. The complete use of the Ngepan Iban will symbolize the status of the wearer and her family. 
There is a significant difference in the enrichment of Ngepan Iban who lives in Batang Rajang and other the Iban areas. Whereas the Iban in the Batang Rajang area tends to use beaded ornaments as a special characteristic in celebrating their traditional costume compared to the Iban who lives in the Saribas, Skrang, and Batang Ai areas who prefer silver accessories as the main ornament in enriching the traditional costume. This is due to cultural assimilation between the Iban tribe in Batang Rajang and the Urang Ulu tribe who tend to use beads as the main decoration in their culture. In the past, apart from cultural objects such as ceramics, beads were also very valuable assets for the indigenous people on the Borneo Island, they obtained these beads from traders who sailed from China to Borneo through the barter system, where they would exchange rice for goods. Other essentials from China such as ceramics, beads, and textiles.

As for the Iban people who domicile in the Saribas, Skrang, and Batang Ai areas, they are fond of silverware, so they have adapted using silver in innovation and cultural object creation. For the Iban, apart from ceramics, objects that are produced from silver are a status symbol of wealth and pleasure. The more silver collections a family have, the higher their rank in social status in the longhouse. Therefore, in ancient times it was not surprising why the Iban people liked to grow hill rice on a large scale, the aim was to buy, and own objects made of silver as an heirloom and a symbol of wealth status. They will also feel embarrassed when talked about by another the Iban if they do not own or borrow the Ngepan Iban. These factors motivated the Iban to diligently cultivate rice and expand their power through the Ngayau expedition to obtain items such as tajau (vase), gongs, and silver accessories so they would not sag in front of other Iban communities.

There are some significant changes that can be clearly seen in the aesthetic value of Ngepan Iban especially in terms of manufacturing materials and application practices among the Iban especially in terms of manufacturing materials and application practices among the Iban today. In ancient times, the material for making Ngepan Iban accessories was using pure silver specially forged by the Memaloh ethnic, they learned silver forging techniques from traders from China. Therefore, every forged accessory has a high value, weight, and durability to be stored as an inheritance for a long period of time. Apart from that, the Iban also produces natural-based textile weaving to make Kain Kebat as the basis of Ngepan Iban. Natural ingredients such as Engkerabai leaves will be used as dyes to produce red and brown colors, while taya will be used as yarn for the process of weaving the kain kebat. The process of making Kain Kebat is very taboo and full of customs. The Iban believes that Pua and Kain Kebat is an introduction to Petara and was raised as a sacred cultural artifact in the Iban ceremonies and rituals. 
Before producing weave, the Iban women should wait for a good and happy dream from Petara (God). This intended to get blessings from Petara (God) and to ensure the weaving process will run smoothly.

Nowadays, in line with the development of globalization, the material in the manufacture of Ngepan Iban accessories have existed in various variations. Ngepan Iban accessory material that was once made of pure silver has been replaced with aluminium sheets as an alternative in producing more modern Ngepan Iban accessories due to the cheap market price factor and easy to shape according to the taste of the owner. Besides, the manufacture of Kain Kebat is also modernized using yarns that are available in the market and come in a variety of colours. Indirectly, the Iban is no longer rely entirely on natural resources to produce their woven textiles as their ancestors have done in the past. The practice of the belief in sacred power in the process of weaving Kain Kebat is fading among the younger generation of Dayak Iban due to the new belief factor that they adhere which is Christianity. Indeed, the impact of globalization has an impact on the authenticity of Ngepan Iban especially in terms of its material use and aesthetic practices. Thus, to ensure the authenticity and value of Ngepan Iban tradition continues to be preserved, Tun Jugah Foundation, Dayak Chair Foundation together with public institutions such as University Malaysia Sarawak must actively strengthen the Iban awareness through workshops, seminars, and academic discussions to increase understanding and awareness on the upkeep of Ngepan Iban in the future. So, its sustainability remains relevant in the Iban culture in Sarawak.

\section{CONCLUSION}

In conclusion, until to this moment, the the Iban still preserve and maintain Ngepan Iban as their identity and icon in Iban culture. Although Ngepan Iban has undergone significant changes in terms of originality in the enrichment of materials and clothing as a result of various factors such as cultural assimilation, changes in globalization, and even cultural modification, however, the lban themselves still have a passion to preserve Ngepan Iban as an important cultural heritage in Sarawak. Therefore, through this research, it is expected to have an effective and progressive impact to regenerate the spirit of the Iban culture to continue persistently preserve the Ngepan Iban as a cultural heritage from the ancestors of the past, so that it will continue to be preserved for the future. 


\section{ACKNOWLEDGEMENT}

We sincerely thanks Research Innovation and Enterprise Centre (RIEC), University Malaysia Sarawak for funded this research paper under UNIMAS Post-Graduate Student Research (F03/PGRG/1799/2019).

\section{REFERENCES}

1. Bernadette P.R \& Elmhirst.R .2008. Gender and Natural Resources Managment:Livehoods Mobility and Interventions. London: United Kingdom: International Development Research Center.

2. Buckland, M. K. 2017. Before the antelope: Robert Pagès on documents. Proceedings from the Document Academy, 4(2), 6.

3. Darmawan, K. Z. (2008). Penelitian etnografi komunikasi: tipe dan metode. Mediator: Jurnal Komunikasi, 9(1), 181-188.

4. E.T, Hall.1990. Understanding Cultural Differences. Massachusetts: Intercultural Press, Inc

5. Fong. M Chuang.R. 2003. Communicating Ethnic and Cultural Identity. Maryland: Rowman \& Littlefiled Publishers.

6. Hanson, W. E., Creswell, J. W., Clark, V. L. P., Petska, K. S., \& Creswell, J. D. (2005). Mixed methods research designs in counseling psychology. Journal of counseling psychology, 52(2), 224.

7. Jasmi, K. A. 2012. Metodologi Pengumpulan Data dalam Penyelidikan Kualitatitif in Kursus Penyelidikan Kualitatif Siri 12012 at Puteri Resort Melaka on 28-29 Mac 2012. Or-ganized by Institut Pendidikan Guru Malaysia Kampus Temenggong Ibrahim, Jalan Datin Halimah, 80350 Johor Bahru, Negeri Johor Darul Ta'zim

8. Jusy Sambai Anak Javeril. 2018. Ngepan Batang Al (Iban Women Traditional Attire) Presentation Through Light Painting Photography. Kota Samarahan: University Malaysia Sarawak.

9. Kamus Dewan Bahasa, Edisi III .1994. Kuala Lumpur: Dewan Bahasa dan Pustaka.

10. Lund, N. W., \& Buckland, M. 2008. Document, documentation, and the Document Academy: introduction. Archival Science, 8(3), 161.

11. Marican, S. 2005. Kaedah penyelidikan sains sosial. Kuala Lumpur: Prentice Hall/Pearson Malaysia.

12. Mead, G.H. 1929. 'The Nature of the Past', in J.Coss (ed.), Essays in honor of John Dewey .New York: Henry Holt.

13. Misztal, B. 2003. Theories of social remembering. McGraw-Hill Education (UK).

14. Moha, E. 2005. Multilingualism, Cultural Identity and Education in Morocco. International Journal of the Sociology of Language, 4:1-7. 
15. Moleong, LJ. 1989. Metodologi Penelitian Kualitatif. Bandung: Remaja Rosdakarya.

16. Payne, Robert.1986. The White Rajah of Sarawak. Singapore: Oxford University Press.

17. Pringle, R. 1970. Rajahs and rebels: the Ibans of Sarawak under Brooke rule, 1841-1941. Universiti Malaysia Sarawak.

18. Sandin, B. 1967. The Sea Dayaks of Borneo before white rajah rule. London, Melbourne.

19. Sholikhah, R. 2017. Pengembangan Modul Interaktif Busana Daerah sebagai Media Pengenalan Budaya Indonesia. TEKNOBUGA: Jurnal Teknologi Busana dan Boga, 5(2):10-21.

20. Simonson, T. S., Xing, J., Barrett, R., Jerah, E., Loa, P., Zhang, Y., .. \& Mowry, B. (2011). Ancestry of the Iban is predominantly Southeast Asian: genetic evidence from autosomal, mitochondrial, and Y chromosomes. PloS one, 6(1), e16338

21. Sutlive Jr, V. H. 1992. Tun Jugah of Sarawak: Colonialism and Iban Response, Kuala Lumpur: Fajar Bakti SDN.

22. Tahir, A., \& Mohd Noor, A. (2017). Visual Operasi Menghapus Serangan Lanun di Nusantara Dari Laporan The Illustrated London News, 1845-1872. SEJARAH: Journal of The Department of History, (2):22.

23. T, Gavin. 1991. Kayau Indu: The Warpath of Women. Sarawak Museum Journal, $X L I I, 5-10$.

24. Yussof, W. A. 2006. Identiti Budaya Melayu dalam Pembangunan Industri Budaya. Jurnal Antarabangsa Pengajian Melayu (pp. -). Kuala Lumpur: Universiti Malaya. 